Volume 5, Issue 1, February 2020, pp. 80-93

DOI: $10.23917 /$ jramathedu.v5i1.9523

p-ISSN: 2503-3697, e-ISSN: 2541-2590

\title{
Junior high school mathematics teachers' knowledge in calculators
}

\author{
Isaac Bengre Taley ${ }^{*}$, Matilda Sarpong Adusei² \\ ${ }^{1}$ Mampong Technical College of Education, Ghana \\ ${ }^{2}$ Agona SDA College of Education, Ghana \\ *Corresponding author: bengre.isaac@gmail.com
}

\begin{tabular}{l} 
ARTICLE INFO \\
\hline Article history: \\
Received: 14 December 2019 \\
Revised: 5 February 2020 \\
Accepted: 7 February 2020 \\
Published online: 28 February \\
2020 \\
Published regularly: February \\
2020
\end{tabular}

Keywords:

Scientific calculator, calculator competence, teacher

characteristics, junior high school mathematics teacher.

\section{ABSTRACT}

Helping junior high school students to use calculators and computers for problem solving and investigating real-life situations is an objective of the junior high school mathematics curriculum in Ghana. Ironically, there is a technological drought in junior high school mathematics instruction in Ghana, with a suspicion that mathematics teachers' competency in the use of calculators for teaching may be the source of this lack of use. This study sought to establish a correlation between junior high school mathematics teachers' competence and the motivation supporting the use of calculators in teaching. A descriptive survey comprising of a test and questionnaire was used to collect data from junior high school mathematics teachers in an educational district in Ghana. Teacher characteristics such as educational attainment, age, and gender in relation to teachers' competency in the use of calculators were discussed in the study. The results showed that about $70 \%$ of the teachers exhibited a low level of calculator competence. Besides, novice teachers outperformed expert teachers in the calculator competency-based test. Additionally, mathematics teachers' enthusiasm for using calculators in teaching was directly associated with the teachers' level of competency. The findings may send a signal to stakeholders in their efforts to revising the Ghana JHS curriculum in order to actualize the curriculum desire for the integration of technology in the teaching and learning of JHS mathematics.

(C) 2020 Universitas Muhammadiyah Surakarta

\section{Introduction}

Calculators, just as any technological tool, have become an integral part of teaching and learning mathematics in Ghana (Ministry of Education, 2007) and elsewhere in Africa (Ochanda \& Indoshi, 2011). The technology principle of the National Council of Teachers of Mathematics' asserts that "Technology is essential in teaching and learning of mathematics; it influences the mathematics that is taught and enhances students' learning" (NCTM, 2000, p. 24). The document further promotes calculators and other technologies as essential mathematical tools to the extent that using calculators has become both an innovation and an aid to entering the technological world. However, a teacher's ability to engage appropriately with this technological tool depends on his/her knowledge and skill about

To cite this article:

Taley, I. B., \& Adusei, M. S. (2020). Junior high school mathematics teachers' knowledge in calculators. JRAMathEdu (Journal of Research and Advances in Mathematics Education), 5(1), 80-93. doi:https://doi.org/10.23917/jramathedu.v5i1.9523 
the tool (Ely, 1999; Pierce \& Ball, 2009). (Note: hereafter, and unless otherwise stated in this paper, calculator refers to scientific calculator).

Whereas some opponents argue that the use of calculators threatens students' ability to develop basic computation skills and as well breeds laziness among students (Mason, 2010; Satianov, 2015), its usefulness in mathematics instructions cannot be underestimated. Miles (2008) for instance, suggested that calculators aid in the development of mathematical concepts. Miles further asserted that calculators could be used as self-drill apparatus that serve to enhance the problem solving abilities of learners. Additionally, Miles held the view that the use of calculators reduced the amount of time spent in computation. In a similar measure, technological affordances such as calculators exert enormous impact on the teaching and learning of mathematics. Perhaps, calculator users are able to solve problems that hitherto would have been very difficult if not impossible. Additionally, greater opportunities for more exploration, better representation and effective communication of results are demonstrated through the power calculators (NCTM, 2000).

Given the widespread agreement among mathematics educationists on the necessity to equip teachers with the needed knowledge of technology in the use of calculators and other technological tools, it follows that teachers are trained in how to incorporate calculators in mathematical instruction and learning (Salani, 2013). In this light, recommendations have been made in Ghana for a modification of the mathematics curriculum for teacher training, to equip trainees in the use of calculators in mathematics instruction (Asare-Inkoom, Apau Gyamerah, \& Najimudeen, 2008; Mereku et al., 2007). Colleges of Education ( $\mathrm{CoE}$ ) in Ghana have been accredited to provide content, pedagogic and technological training of basic school mathematics teachers (Government of Ghana, 2012). The training of pre-service mathematics teachers in CoEs is to equip them with the knowledge on how to use, apply and integrate technology in the teaching of mathematics. Yet, mathematics teachers in junior high schools (JHS), similar to secondary school mathematics teachers in Ghana (Agyei \& Voogt, 2011), seldom integrate technology in their instruction. Evidence to this is Amanyi, Sigme, \& Lloyd (2016) report that in Ghana, JHS mathematics lessons are primarily characterized by paper-pencil calculations. It is not as if the education system inhibits the use of calculators in teaching mathematics at the JHS although the use of calculators in the Basic Education Certificate Examination - BECE (External examination taken by students at the completion of JHS) have been a subject of debate (Mereku et al., 2007); Its use in teaching is not only encouraged but mandatory. This is because the JHS mathematics curriculum intends to help students use calculators and computers for problem solving and investigation of real-life situations (Ministry of Education, 2007).

The limited use of calculators in junior high school mathematics lessons raises questions about teachers' ability to use calculators in Ghana. Whilst the junior high school mathematics teachers' competence in the use of scientific calculators remains a suspicion, there is ample evidence that Ghana's basic school mathematics teachers are challenged in the use of other types of calculators. For instance, Wilmot (2015) found that Ghanaian teachers lag behind their USA counterparts on a KAT item which was easily answerable using the graphical calculator but a deficiency on the part of the Ghanaian teachers might have caused them. Despite a plethora of research on teachers' attitudes, beliefs and perceptions toward the use of calculators (Adabor, 2008), it seems there is less research on teachers' level of competency in the use of calculators.

The purpose of this study was to examine Ghanaian junior high school mathematics teachers' competence to use calculators for mathematical computation and their ability to 
use the calculators in teaching. Subsequent to this result, the researchers also sought to correlate the teacher's competency with their motivation for using calculators in their teaching.

To achieve the aims of this study, the researchers sought to answer the overarching research question of how well Ghanaian junior high school mathematics teachers' competency in calculators correlated with their perceived motivation for using calculators in teaching. To this end, two sub-questions were asked. The first question was: "What is the current calculator competency level of JHS mathematics teachers in Ghana? Here, the researchers sought to examine how well mathematics teachers performed on a test that was answered using the calculator. Intrinsically, the study determined whether teacher characteristics such as age, teaching experience and category of the teacher might expose differences between and among the mathematics teachers. The second question for this study was: "What perceived factors influenced JHS mathematics teachers in Ghana to use calculators during teaching? On the basis of this question, the mathematics teachers' competency in calculators was correlated with their perceived motivation for using calculators in teaching.

Though a myriad of factors has been found to impact the use of technology in the teaching and learning of mathematics in Ghana, the focus has largely being tilted towards ICT and computers, leaving handheld calculators largely unexplored. Technology competency has been established by research as one of the significant factors that influence technology use in teaching and learning interactions (Agyei \& Voogt, 2011; Pelgrum, 2001; Salani, 2013). Pelgrum (2001) bemoaned the impact of teachers' competency gap in technology on the success of educational innovations, claiming that the success in vitalizing education through technological innovations depended on the technological competence of teachers. Apart from singling out competency, other teacher characteristics such as age, teaching experiences, gender, and educational qualification also directly influence the use and adoption of technology in general (Afshari, Bakar, Luan, Samah, \& Fooi, 2009).

The Adopter-based theories (Surry, 1997) provided a theoretical anchor to this study. The adopter based (Instrumentalist) theory focuses on social conditions, human, and interpersonal dimensions necessary for innovation, diffusion, and use. The ultimate implementer of innovation in this theoretical framework is seen as a primary agent of change who implements the innovation in a practical setting. Tessmer (1990), for example, held the view that several factors accounted for the adoption or rejection of innovation in a technological context such as in instruction. According to Tessmer, the factors responsible for the adoption or rejection of innovations were hinged on the user of the innovation. Consequently, Tessmer argued that the level of the technical superiority of an innovation/product is not the only factor that influences its use. But, personal and interpersonal factors can play a more substantial role in the use of technology innovations than technological superiority (Surry \& Farquhar, 1997).

Ghana's JHS Mathematics teachers' use of calculators might not only be affected by the power and efficiency of the calculators themselves but also human conditions classified as teacher characteristics. Schools and for that matter, government agencies overseeing the implementation of the JHS syllabus could influence some of these characteristics, yet not all. Conceptually, factors related and unrelated to calculator technology influence teachers' use of calculators (Figure 1). Operationally, factors related to calculator technology are the combination of calculator knowledge and skills of JHS mathematics teachers, whereas, unrelated factors are the non-manipulative teacher characteristics/factors such as gender, age, teaching experience and ownership of calculators (Afshari, Bakar, Luan, Samah, \& Fooi, 2009). 


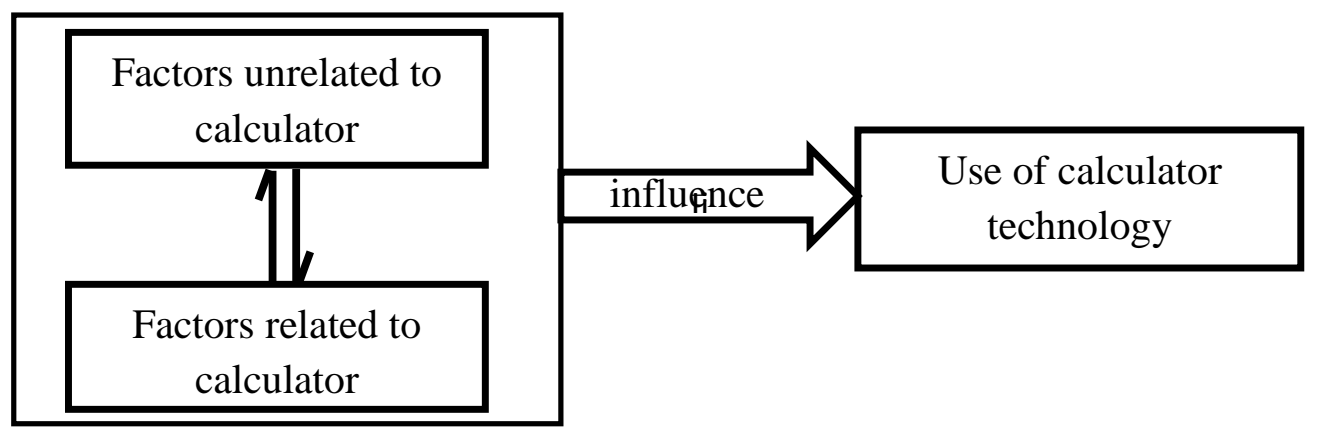

Figure 1. Interactions of factors influencing the use of calculator technology

\section{Research methods}

A descriptive survey design was used to examine the competency level of Ghana's JHS mathematics teachers in the use of calculators. Kothari (2004) held the view that descriptive survey studies aim to provide a description of the characteristics of a particular individual, or of a group of individuals. Additionally, Ochanda and Indoshi (2011) explained that a descriptive survey is a fact-finding research design in educational research where accurate and primary information regarding teachers' use of calculators could be obtained. Though different types of descriptive research methods exist (Hale, 2011; Jackson, 2015), here in this study, a survey method was undertaken in which mathematics teachers responded to a set of questionnaires and test items. By so doing and within a relatively short period of time, test scores and responses on teachers' competence in using calculators and the motivation for using calculators in teaching mathematics respectively were concurrently collected from the junior high school mathematics teachers. Creswell and Creswell (2017) described the survey design as a non-experimental quantitative approach that is suitable for gathering a numeric description of a state of affairs of a population by studying the desired characteristics in a sample of that population. It, therefore, answers the question of 'what is?' and this sits well with the research questions in this study.

A total of 97 JHS mathematics teachers drawn from an educational district in Ghana participated in the study. The participants included 46 student-teachers who had just completed a yearlong practicum at the JHS and 51 practicing mathematics teachers. The educational district had 59 JHS distributed in eight circuits. The number of mathematics teachers in each school varied from one to three depending on the number of streams. A stratified sampling (Alvi, 2016) was used to select respondents from five circuits since the teachers were already in their natural strata. Some practicing teachers declined to respond to the questionnaires because of the test component. Whereas some wanted to take the questionnaire home, others were frank to say that they could not use the calculators. Within a week of an intensive visit to schools, only 51 responded positively. Through snowballing, 46 student-teachers who taught JHS 1 mathematics for the entire practicum period also participated in this study.

The main instrument for the data collection comprised a set of questionnaires and a competency-based test which was developed and administered by the researchers. Since we could not assess an existing validated instrument, the researchers in consultation with one mathematics teacher educator in a College of Education in Ghana, designed a calculator competency-based test. The test items demanded from respondents two things. Firstly, the teachers were to provide answers to the questions with the aid of a calculator without doing any form of paper-pencil computations, and secondly, they were to describe the 
steps to be followed in using a calculator to compute a task. In this regard, the junior high school mathematics teachers could demonstrate their skill and the understanding of the calculator operation and function keys. The choice for these two tests of competence in using the calculator is premised on the notion that a person's technological competence is not just about the theoretical and factual information of using calculators, but also the selection and performance ability to make the right choice of keys and functions at the right step. The questionnaire component (Table 4) of the instrument was an 11-item four-point Likert scale questionnaire that sought to explore teachers' perception of what motivated them in using calculators in the teaching of mathematics. The responses to the four-point Likert scale ranged from a score of one through to four representing 'strongly disagree to strongly agree respectively.

A pilot test of the research instrument was carried out on 18 teachers who were pursuing degree programs (mathematics major) over a 4-week interval period. The calculator use questionnaire yielded a Cronbach alpha reliability coefficient of 0.719 which was good for implementation (Tavakol \& Dennick, 2011). With regards to the competencebased test, an internal consistency reliability test yielded a 0.806 Pearson correlation at 0.01 (2-tailed) significance level (Liebe, Meyerhoff, \& Hartje, 2012; Tavakol \& Dennick, $\underline{2011})$. However, using the Escudero, Reyna, and Morales (2000) discrimination index and the marking scheme drawn for the test, some items on the pilot test were either modified and/or replaced based on the pilot test.

For instance, the problem "For the standard deviation, a student enters ' $\sqrt{ }$ ' 'C' 'C' ' 4 ' ' '-

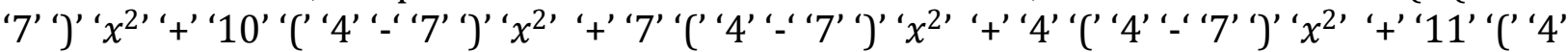
'-' '7' ')' ' $x^{2}$ ' ')' ' $\div$ ' ' 6 ' =' and gets the answer 6.63 . Which other approaches could s/he have used?" was deleted because it had a discrimination index of zero. Simply, none of the teachers who participated in the pilot test attempted answering this question. Whereas some claimed they had forgotten the algorithm, others were not sure of any other approach. Other questions such as

1. Solve for $x$ and $y$ simultaneously using the calculator: $2 \mathrm{x}-\mathrm{y}=5$ and $2 \mathrm{x}+\mathrm{y}=7$;

2. Increase 250 by $25 \%$

3. How do you access the decimal functions on the calculator?

did not get the needed responses and had to be rephrased. In question (a) and (b), the teachers were rather using the calculator only to verify their answers as in figure 2 . In question (c), the teachers had misconstrued the question to mean the location of the decimal function key. However, during the interaction phase after the pilot test, the teachers suggested a re-framing of these questions which the researchers found relevant. Subsequently, questions (a), (b) and (c) were rephrased respectively as

1. Indicate systematically keys that would lead to solving simultaneously: $2 x-y=5$ and $2 \mathrm{x}+\mathrm{y}=7$.

2. Indicate systematically keys that would lead to increase 250 by $25 \%$

3. After computation, how do you access a "decimal answer" on the calculator?

In order to maintain the 16 items as before the pilot testing, the deleted question which had a discrimination index of zero was replaced with a similarly framed question 'What did a student do wrong inputting $2[$ SHIFT $]\left[x^{2}\right] \times 5$ for computing $2^{3 \times 5}$ ?' 

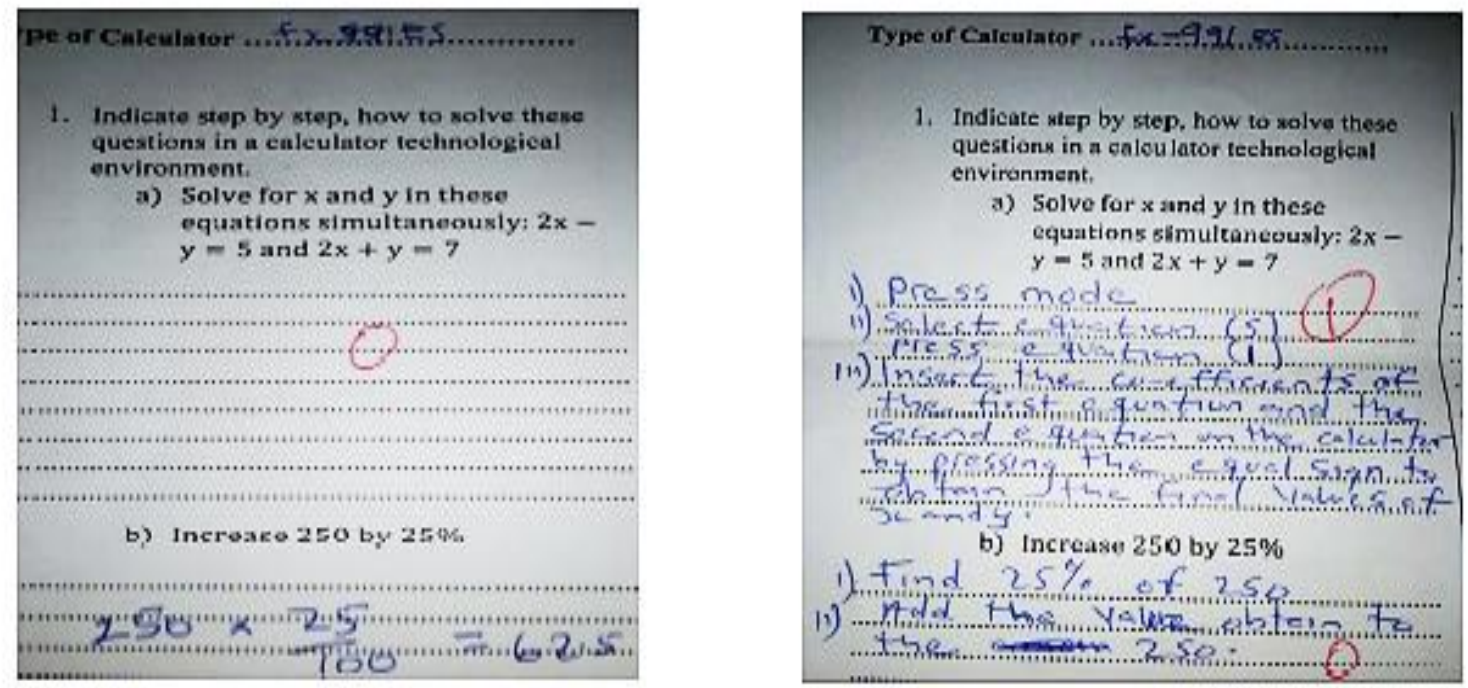

Figure 2. Sample of solutions during the pilot test

The modified research instrument (that is, the instrument after pilot testing) was distributed to the mathematics teachers at their various schools where they responded in the presence of the researcher. Even though three brands of calculators (CASIO FX-115ES Plus, HP 35s, CASIO fx-991ES PLUS) were made available, the CASIO fx-991ES PLUS calculator was preferred by the teachers. Responses from the 11-item four Likert scale questionnaire were included in an exploratory factor analysis (Principal axis factoring with varimax-rotation), to identify possible perceived factors that motivated the mathematics teachers to use calculators in teaching. The sample size of 97 fell within Tabachnick, Fidell, and Ullman (2007) 1 to 10 criteria (about eight persons for a variable).

Permission to conduct the study was sought from head teachers. Once permission was granted by the head teacher, the purpose and procedure for the study were explained to the mathematics teacher(s) who either agreed or declined to participate without coaxing. Data assembled was analyzed descriptively using means and standard deviations. Analysis of variances for equality of means within and between groups was performed. Effect size statistics were determined based on Cohen's $d$ benchmark (as cited in Agyei \& Voogt, 2015).

\section{Results and discussion}

In the following analysis, we defined the independent variables as follows. To begin with, the gender of a teacher was explained as either a male or a female teacher. Also, teachers' teaching experience with respect to the number of years of teaching basic school mathematics was classified into three categories. These are novice teachers, those who had at most three years of teaching, intermediate teachers were those who had taught for a period between 4 and 10 years, and expert teachers were teachers with at least 11 years of teaching JHS mathematics.

Furthermore, the maturity of the teachers with respect to their age was defined as either a young adult at most 24 years old or an older adult of at least 25 years old. This classification is in agreement with standards acceptable for admission into institutions of higher studies in Ghana such as GIMPA (2019). In addition, the teacher type/category referred to the statue of the teacher as to either a student-teacher or a practicing teacher. During a familiarisation visit to some of the junior high schools in the study area prior to 
data collection, we found that some students from a college of education were having their practicum. Hence the inclusion of teacher-trainees in the study. Lastly, teachers' highest professional qualification for teaching mathematics at the JHS was described by their academic attainment. This included secondary school certificate holders, diploma holders, and degree holders.

Research has shown conflicting results of the relationship between these aforementioned independent variables and mathematics teachers' perceived competence in the use of technological tools such as the calculator. For instance, Salani ( $\underline{2013})$ observed that mathematics teachers differed in their perceived competence in the use of calculators by teachers' gender and teaching experience. With a calculator as a technological tool,

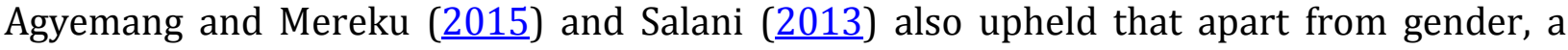
mathematics teacher's use of technology in Ghana was not significantly influenced by age/maturity and teaching experience. Riding on the same argument, Agyei and Voogt (2011) claimed that practicing teachers were superior to pre-service/student-teacher in technology use competency.

Each item on the competency test was scored on a scale of 0 to 2 . A correctly answered question attracted 2 marks, 1 mark for a partially correct answer and a 0 mark for a wrong solution or an unanswered question. Thus, the optimum score could have to be 32 since there were 16 questions. With a median score of 16, we decided without recourse to any literature to categorize the score obtained by a mathematics teacher on the competency-based test as a low or high score. On that basis, a teacher was either classified as a low scorer or a high scorer. Low scorers obtained a score of 16 or lower and a higher scorer obtained a score of 17 or better on the test. Approximately $70 \%(M=10.16 ; S D=$ 4.363; $N=68)$ of the teachers obtained a low score, and approximately $30 \%(M=19.38 ; S D$ $=4.248 ; N=29$ ) of the teachers obtained a high score. The scores were also normally distributed among the teachers (Shapiro-Wilk test of significance $=.145$ ). Considering the descriptive statistics, it could be inferred that the teachers in the study underperformed in the test. An independent sample t-test on the difference in performance was statistically significant $t(87.11)=-13.131, p<.001$, two-tailed, with a very large effect size (Eta square = .544 ) observed. A $99 \%$ confidence interval on the difference was within range (-11.066 to 7.369). These statistics suggest that in general, and with respect to the study area, junior high school mathematics teachers' knowledge in the use of calculator knowledge is low. Above all, the test was sufficient to disaggregate junior high school mathematics teachers according to their competency in calculator technology.

A Pearson product moment correlation was executed to test for possible association between teachers' calculator competency scores and the independent variables identified. Further association was tested among the independent variables for which linear relationships (Pallant \& Manual, 2007) were established. For example, a negatively weak correlation was found between a teacher's calculator competency score and their academic attainment, $r=-.28, n=97, P<.005$. Among the predictor variables, teaching experience correlated: (1) strongly and positively with academic qualification $(r=.68, n=97, P<$ .005); (2) moderately strongly and positively with age $(r=.42, n=97, P<.005)$; (3) but negatively with teacher type $(r=-.54, n=97, P<.005)$. A positively large and negatively large association between age and academic qualification $(r=.57, n=97, P<.005)$ and teacher type $(r=-.56, n=97, P<.005)$ respectively. A very high negative association between academic qualification and teacher type $(r=-.84, n=97, P<.005)$ was recorded. The correlations among the variables ranged from negative to positive, from small to large but some correlation were not significant (Taylor, 1990). 
Table 1

Differences in teacher calculator competency per teacher characteristics within levels of teacher Characteristics

\begin{tabular}{|c|c|c|c|c|c|c|c|c|}
\hline \multirow{2}{*}{ Variable } & \multicolumn{3}{|c|}{ Low score } & \multicolumn{3}{|c|}{ High score } & \multirow{2}{*}{ Sig } & \multirow{2}{*}{$\begin{array}{l}\text { Effect } \\
\text { size }\end{array}$} \\
\hline & $\mathrm{N}$ & $\mathrm{M}$ & SD & $\mathrm{N}$ & $\mathrm{M}$ & SD & & \\
\hline \multicolumn{9}{|l|}{ Maturity (Age) } \\
\hline Young adult & 23 & 11.87 & 3.389 & 11 & 18.82 & 1.328 & $.000^{*}$ & .571 \\
\hline $\begin{array}{l}\text { Old adult } \\
\text { Teaching experience }\end{array}$ & 45 & 9.29 & 4.576 & 18 & 19.72 & 2.967 & $.000^{*}$ & .567 \\
\hline Novice & 48 & 10.77 & 3.855 & 23 & 19.04 & 1.846 & $.000^{*}$ & .579 \\
\hline Intermediate & 16 & 8.56 & 5.266 & 5 & 20.60 & 4.615 & $.000^{*}$ & .524 \\
\hline Expert & 4 & 9.25 & 5.737 & 1 & 21.00 & . & .164 & .528 \\
\hline \multicolumn{9}{|l|}{ Teacher category } \\
\hline Student teacher & 28 & 11.79 & 3.594 & 18 & 19.06 & 1.765 & $.000^{*}$ & .590 \\
\hline Practising teacher & 40 & 9.03 & 4.532 & 11 & 19.91 & 3.390 & $.000^{*}$ & .527 \\
\hline \multicolumn{9}{|c|}{ Academic qualification } \\
\hline $\begin{array}{l}\text { Secondary } \\
\text { certificate }\end{array}$ & 31 & 11.68 & 3.945 & 18 & 19.06 & 1.765 & $.000^{*}$ & .544 \\
\hline Diploma & 20 & 9.15 & 3.760 & 8 & 19.88 & 3.944 & $.000^{*}$ & .635 \\
\hline $\begin{array}{l}\text { Degree } \\
\quad \text { Gender }\end{array}$ & 17 & 8.59 & 5.038 & 3 & 20.00 & 1.732 & $.001^{*}$ & .446 \\
\hline Males & 59 & 10.27 & 4.495 & 29 & 19.38 & 2.484 & $.000^{*}$ & .545 \\
\hline Females & 9 & 9.44 & 3.504 & 0 & & & & \\
\hline
\end{tabular}

${ }^{*} p<.005 ;$ analysed with $t$-test computed at .01 alpha level

Secondary school certificate holders are student-teachers yet to graduate with Diploma

Table 2

Differences in teacher calculator competency per teacher characteristics within groups of teacher characteristics

\begin{tabular}{|c|c|c|c|c|c|c|c|c|c|c|c|c|}
\hline & \multicolumn{2}{|c|}{ Teacher type } & \multicolumn{2}{|c|}{ Gender } & \multicolumn{2}{|c|}{ Maturity } & \multicolumn{3}{|c|}{ Teaching experience } & \multicolumn{3}{|c|}{$\begin{array}{c}\text { Academic } \\
\text { qualification }\end{array}$} \\
\hline & $\begin{array}{c}\text { Practi- } \\
\text { cing }\end{array}$ & Student & Male & Female & Young & Old & Novice & $\begin{array}{c}\text { Inter- } \\
\text { mediate }\end{array}$ & Expert & Sec & Dip & Deg \\
\hline $\mathrm{N}$ & 51 & 46 & 88 & 9 & 34 & 63 & 71 & 21 & 5 & 49 & 28 & 20 \\
\hline M & 11.37 & 14.63 & 13.27 & 9.44 & 14.12 & 12.27 & 13.45 & 11.43 & 11.6 & 14.39 & 12.21 & 10.3 \\
\hline SD & 6.226 & 4.668 & 5.83 & 3.504 & 4.368 & 6.312 & 5.124 & 7.257 & 7.232 & 4.873 & 6.191 & 6.258 \\
\hline $\begin{array}{l}\text { Sig } \\
\text { eta }\end{array}$ & \multicolumn{2}{|c|}{$0.005^{*}$} & \multicolumn{2}{|c|}{0.057} & \multicolumn{2}{|c|}{0.132} & \multicolumn{3}{|c|}{0.323} & \multicolumn{3}{|c|}{$0.019^{*}$} \\
\hline sq. & \multicolumn{2}{|c|}{0.081} & \multicolumn{2}{|c|}{0.038} & \multicolumn{2}{|c|}{0.024} & \multicolumn{3}{|c|}{0.024} & \multicolumn{3}{|c|}{0.081} \\
\hline
\end{tabular}

${ }^{*} p<.005$; analysed with $t$-test computed at .05 alpha level

Secondary school certificate holders are student-teachers yet to graduate with Diploma

Table 1 shows how the mathematics teachers differed in their competence in calculators. The mathematics teachers were categorized according to five teacher characteristics with respect to their level of calculator competence. Expert teachers were statistically not different $(F(1,98.75)=3.355, p=.164)$ in their mean score on the competency-based test. That is apart from the sub-category of experts, all other levels of 
categorizing teachers depicted a sharp difference in their performance on the competency test. The gap between high competency and low competency was glaringly obvious.

A further analysis (Table 2) of the competence showed significant differences within teacher type $(F(1,95)=8.355, p=.005)$ and academic qualification $(F(1,94)=4.135, p=$ .019). The difference in teacher type was in favour of student teachers $(M=14.63, S D=$ 4.668) with a relatively small effect (8.1\%) on competency. Unlike, Agyei and Voogt (2011) who found that practicing teachers were more competent technologically than student teachers, this study, however, found that student teachers were more competent in the use of calculators than practicing teachers. On academic qualification, a Tukey HSD post hoc test at $95 \%$ confidence level showed a 0.019 significance difference between secondary school certificate holders and degree holders in favour of the former. The effect size was however low (.081). It was envisaged that holders of higher education certificates in mathematics would have been more competent but that was not seen to be the case. Examining the data revealed that of the 20 mathematics teachers with degree certificates, $45 \%$ (09) pursued a bachelor of education B.Ed (Mathematics) and the remaining 55\% (11) have bachelor's degrees in other subjects such as social studies. What the researchers could not confirm was the module of the degree program (distance or regular) and content of study therein. Among the 28 diploma holders, 10 held a Diploma in Basic Education DBE (mathematics major), while the remaining 18 had DBE in other subjects other than mathematics. The secondary school certificate holders were all 2019 final students pursuing DBE with mathematics as a major subject of study. These student teachers had gone through a method of teaching basic school mathematics course barely a year earlier, during which they were trained on how to teach with calculators. The high competency level of these student teachers in the use of calculators could be that their calculator knowledge was still fresh in memory and/or they indeed did use the calculators during the teaching practice. All the student teachers did their teaching practice in JHS one (1) class (grade 7) where introduction to calculators is a topic in the JHS mathematics syllabus in Ghana (Ministry of Education, 2007).

On the issue of maturity which was simplified as age, table 2 reveals that there was significantly no difference in competency level with age. Furthermore, a series of 10 threeway analysis of variance (ANOVA) at 99\% confidence level were computed to explore how the JHS mathematics teachers from an educational district in Ghana differed in their competency ability on calculators. There was no single statistical difference observed among the interactions and main effects (Table 3). The interactions were sufficient to control the univariate main effect observed in teacher type.

Additional exploration of variance on the impact of maturity and academic attainment on calculator competency yielded no statistically significant interaction result $(F(1,92)=.143, p=.706)$. The interaction effect between gender and academic attainment on the calculator competence of teachers was not statistically significant $(F(2,91)=1.260$, $p=.265)$. There was equally no statistical difference main effect for gender $(F(1,92)=$ $1.004, p=.319)$. Another test of variance on the impact of gender and teaching experience on the calculator competence of teachers yielded no statistically significant interaction result $(F(1,92)=.589, p=.445)$ at .01 (Pallant \& Manual, 2007). There was equally no statistical difference main effect for gender $(F(1,92)=2.844, p=.095)$. Descriptive data analysis revealed that young adult mathematics teachers were neither intermediate nor expert teachers. All young adults were novices in the teaching of JHS mathematics. Besides, a between-groups analysis of variance indicated that the mean difference in teachers' calculator competency was not statistically significant given the interaction effect of 
academic attainment and teaching experience of JHS mathematics teachers $(F(1,97)=$ $.056, p=.814)$.

Table 3

Differences between groups of mathematics teachers on their calculator competency

\begin{tabular}{lcccccc}
\hline \multicolumn{1}{c}{ Interactions } & $\begin{array}{c}\text { Sum of } \\
\text { squares }\end{array}$ & df & $\begin{array}{c}\text { Mean } \\
\text { squares }\end{array}$ & F & Sig & $\begin{array}{c}\text { Partial eta } \\
\text { square }\end{array}$ \\
\hline Gender*Maturity & 10.283 & 1 & 10.283 & 0.328 & .568 & .004 \\
Maturity*Teacher type & 21.984 & 1 & 21.984 & 0.701 & .405 & .008 \\
Gender*Teaching experience & 2.971 & 1 & 2.971 & .094 & .760 & .001 \\
Gender* Academic qualification & 38.891 & 1 & 38.891 & 1.266 & .263 & .014 \\
Teacher type* Teaching experience & 15.807 & 1 & 15.807 & .496 & .483 & .005 \\
Teacher type * Maturity & 117.447 & 1 & 117.447 & 3.841 & .053 & .041 \\
Maturity*Academic qualification & 110.076 & 1 & 110.076 & 3.600 & .061 & .038 \\
Teaching experience*Academic & & & & & & \\
qualification & 1.780 & 1 & 1.780 & .056 & .813 & .001 \\
Gender*Maturity & & & & & & \\
Gender*Teaching experience & 1.892 & 1 & 1.892 & .057 & .811 & .001 \\
Gender*Maturity & 8.775 & 1 & 8.775 & .265 & .608 & .003 \\
Gender*Academic qualification & .023 & 1 & .023 & .001 & .979 & .000 \\
Maturity*Academic qualification & 33.896 & 1 & 33.896 & 1.063 & .305 & .012 \\
Gender*Teaching experience & .632 & 1 & .632 & .020 & .888 & .000 \\
Gender*Academic qualification & .181 & 1 & .181 & .006 & .940 & .000 \\
Teaching experience*academic & 31.243 & 1 & 31.243 & .976 & .326 & .011 \\
qualification & 3.545 & 1 & 3.545 & .111 & .740 & .001 \\
Maturity*Academic qualification & 2.394 & 1 & 2.394 & .074 & .787 & .001 \\
Teaching experience*Academic & 1.116 & 1 & 1.116 & .034 & .854 & .000 \\
qualification & & & & & & \\
\hline
\end{tabular}

In relation to finding possible perceived factors that motivated the mathematics teachers to use calculators in teaching, the Kaiser-Meyer-Olkin measure of sampling adequacy was 0.705 , above the recommended value of 0.6 , Bartlett's test of sphericity was significant $(\chi 2(55)=275.832, p<.05)$ and communalities beyond 0.03 . The KaiserGuttman eigenvalue rule (at least 1.0 ) yielded three factors that explained approximately $57 \%$ of mathematics teachers' perception. These three factor points were observed on the scree plot inspection. After some reliability analysis, nine items that met the factor loading criteria were retained (see Table 4). The alphas ranged from a low of 0.559 for enthusiasm through to a moderate 0.676 for a lack of anxiety and a high of 0.809 for the instructional tool.

Descriptive statistics on the composite scores for each of the three factors were based on the mean (Table 5). There was statistically no difference within each of the subscales with respect to the mathematics teachers' competence level in calculators use. Thus, irrespective of mathematics teachers' perceptions of the motivation behind their use of calculators in teaching, their competency was not different. 
Table 4

Perceived factors that motivated the use of calculators in mathematics instruction

\begin{tabular}{|c|c|c|c|}
\hline Subscale & $\begin{array}{l}\text { Chronbach's } \\
\text { alpha }\end{array}$ & Items & $\begin{array}{l}\text { Factor } \\
\text { loadings }\end{array}$ \\
\hline \multirow[t]{4}{*}{ Instructional tool } & .809 & $\begin{array}{l}\text { Using calculators in classroom teaching allows me to } \\
\text { exhibit my mastery in the use of calculators }\end{array}$ & .851 \\
\hline & & $\begin{array}{l}\text { Calculator use in classroom teaching enhances my } \\
\text { proficiency in its use }\end{array}$ & .817 \\
\hline & & $\begin{array}{l}\text { I enjoy using calculators for teaching students } \\
\text { mathematics }\end{array}$ & .743 \\
\hline & & $\begin{array}{l}\text { I am increasingly integrating calculators in my } \\
\text { mathematics instructions }\end{array}$ & .667 \\
\hline \multirow[t]{3}{*}{ Enthusiasm } & .559 & $\begin{array}{l}\text { I am competent to use calculators in my } \\
\text { mathematics instruction }\end{array}$ & .685 \\
\hline & & $\begin{array}{l}\text { Calculator use is applicable to all topics in the JHS } \\
\text { mathematics curriculum }\end{array}$ & .621 \\
\hline & & $\begin{array}{l}\text { I prefer using calculators to paper-pencil } \\
\text { computations }\end{array}$ & .498 \\
\hline \multirow[t]{2}{*}{ Lack of anxiety } & .676 & $\begin{array}{l}\text { I do not use calculators in classroom teaching } \\
\text { because they take too much of my time }\end{array}$ & .842 \\
\hline & & $\begin{array}{l}\text { I am reluctant to use calculators in mathematics } \\
\text { instruction because calculators make my teaching } \\
\text { job harder }\end{array}$ & .797 \\
\hline
\end{tabular}

Table 5

Descriptive statistics and differences in means for the subscales $(\mathrm{N}=97)$

\begin{tabular}{|c|c|c|c|c|c|c|}
\hline \multirow{2}{*}{ Subscale } & \multirow{2}{*}{$\begin{array}{c}\text { No. } \\
\text { of } \\
\text { items }\end{array}$} & \multirow{2}{*}{ Total M(SD) } & Low Score & High Score & \multirow{2}{*}{ Sig. } & \multirow{2}{*}{$\begin{array}{c}\text { eta } \\
\text { square }\end{array}$} \\
\hline & & & $\mathrm{M}(\mathrm{SD})$ & $\mathrm{M}(\mathrm{SD})$ & & \\
\hline Instructional tool & 4 & $2.46(.636)$ & $2.42(.619)$ & $2.56(.677)$ & .332 & .010 \\
\hline Enthusiasm & 3 & $2.92(.570)$ & $2.87(.561)$ & $3.05(.582)$ & .172 & .020 \\
\hline Lack of anxiety & 2 & $2.58(.744)$ & $2.50(.743)$ & $2.76(.727)$ & .118 & .026 \\
\hline
\end{tabular}

Investigating the association between mathematics teachers' level of competence within these three subscales revealed a direct and significant relationship with enthusiasm, albeit small. However, the association between calculator competence and teachers' use of calculators in teaching, as a result of their lack of anxiety on one hand, and their view that calculators are seen as instructional tools on the other, were not significant.

\section{Conclusion}

From the results, the competency level of JHS mathematics teachers in this educational district of Ghana is low. The relatively high competence among the student teachers could be attributed to their continuous use of calculators for the purpose of examinations and that discontinued use of calculators, just as for any other technological affordance/tool, would cause knowledge lapse and reduced interest. Practicing teachers' low competence could have resulted from this hypothesis since they hardly use calculators in their teaching. The denial of JHS students from using calculators at examinations, particularly at the BECE, discourages teachers from encouraging their students to use calculators in learning mathematics despite the merits described in the literature. JHS mathematics teachers' low competency with calculators is hidden by this official position. But how long can teachers continue to hide? The time is coming and it is here with us, where technology will drive classroom instruction. Teachers' low competency can, in turn, 
lead to low confidence, discomfort and low enthusiasm in using calculators for teaching and this was made manifest during data collection. The concern is that based on teachers' discomfort for calculators, they may most likely impede students' use of calculators which according to Seeley (2006) is unacceptable in the technological learning environment. If stakeholders are really bent on getting students to use calculators and computers in solving mathematical problems, mathematics teachers should be helped through in-service and professional training in order to build up their knowledge because teachers set classroom interaction agendas.

The study was limited to one educational district in Ghana and captured the views and abilities of only 97 JHS mathematical teachers. The observations here may not be applicable for nationwide generalization, however, districts and regions with similar characteristics may exhibit similar observations. It is expected that subsequent studies would conduct a follow-up inquiry to validate these findings on a larger sample. Additionally, the researchers would recommend an in-depth study on why student teachers could out-perform practicing teachers in the use of calculators.

\section{Acknowledgment}

We, the researchers are grateful to all basic school mathematics teachers who participated in the study.

\section{Bibliography}

Adabor, J. K. (2008). An investigation into elementary school teachers' and high school mathematics teachers' attitudes towards the use of calculators in mathematics instruction and learning: A study of selected schools in Ghana. (Doctoral dissertation, Ohio University. Retrieved From https://etd.ohiolink.edu/!etd.send_file?accession =ohiou1210367584\&disposition=inline

Afshari, M., Bakar, K. A., Luan, W. S., Samah, B. A., \& Fooi, F. S. (2009). Factors affecting teachers' use of information and communication technology. International Journal of Instruction, 2(1). https://doi.org/10.1080/14759390902992527

Agyei, D. D., \& Voogt, J. M. (2011). Exploring the potential of the will, skill, tool model in Ghana. Predicting Prospective and Practicing Teachers' Use of Technology. Computers \& Education, 56(1), 91-100. https://doi.org/10.1016/j.compedu.2010.08.017

Agyei, D. D., \& Voogt, J. M. (2015). Pre-service teachers' TPACK competencies for spreadsheet integration: insights from a mathematics-specific instructional technology course. Technology, Pedagogy and Education, 24(5), 605-625. https://doi.org/10.1080/1475939X.2015.1096822

Agyemang, M. \& Mereku, D. K. (2015). Technology use among Ghanaian senior high school mathematics teachers and the factors that influence it. African Journal of Educational Studies in Mathematics and Sciences, 11, 31-42. https://www.ajol.info/index.php/ajesms/article/download/168997/158461

Alvi, M. (2016). A manual for selecting sampling techniques in research. https://mpra.ub.uni-muenchen.de/70218/1/MPRA paper 70218.pdf

Amanyi, C. ., Sigme, B. ., \& Lloyd, A. (2016). Teachers' perceptions of the usage of calculators in the teaching and learning of mathematics at the junior high school level in Ghana. International Journal of Law, Education, Social and Sports Studies, 3(4), 59-73. https://ijless.kypublications.com/3.4.16/59-73 CHURCHER.pdf

Asare-Inkoom, A., Apau Gyamerah, S., \& Najimudeen, A. M. (2008). Effect of Calculator Use in Mathematics Computation by Junior Secondary School Form Two Pupils: A Case 
Study in the Cape Coast Municipality in Ghana. Mathematics Connection, 6(1), 33-39. https://doi.org/10.4314/mc.v6i1.21512

Creswell, J. W., \& Creswell, J. D. (2017). Research design: Qualitative, quantitative and mixed methods approaches. Thousand Oaks, CA: Sage publications.

Ely, D. P. (1999). Conditions that facilitate the implementation of educational technology innovations. Educational Technology, 39(6), 23-27. https://doi.org/10.1111/1467$\underline{8535.00120}$

Escudero, E. B., Reyna, N. L., \& Morales, M. R. (2000). The level of difficulty and discrimination power of the Basic Knowledge and Skills Examination (EXHCOBA). Revista Electrónica de Investigación Educativa, 2(1), 2. Retrieved From https://redie.uabc.mx/redie/article/view/15/1260

GIMPA. (2019). Admission of candidates to diploma and undergraduate degree programmes for 2019/20 academic year. GIMPA Admissions-to-diploma-and- undergrad-2019202028.10 .19 Full-pg.pdf

Government of Ghana. (2012). Colleges of Education Act, 2012 (ACT 847). Accra: Government of Ghana.

Hale, J. (2011). The 3 basic types of descriptive research methods. Psych Central. https://psychcentral.com/blog/the-3-basic-types-of-descriptive-research-methods/

Jackson, S. L. (2015). Research methods and statistics: A critical thinking approach (3rd ed.). Belmont, CA: Cengage Learning.

Kothari, C. R. (2004). Research methodology: Methods and techniques. New Delhi: New Age International (P) Ltd.

Liebe, U., Meyerhoff, J., \& Hartje, V. (2012). Test-retest reliability of choice experiments in environmental valuation. Environmental and Resource Economics, 53(3), 389-407. https://doi.org/10.1007/s10640-012-9567-1

Mason, A. (2010). Integrating Calculators in the secondary Mathematics Classroom: . Teachers' Attitudes and Perspectives. Online Submission. https://files.eric.ed.gov/fulltext/ED510595.pdf

Mereku, D. K., Donkor, J., Sokpe, B., Addo, G., Klaye, M. K., Incoom, P. K., \& Wilson, R. (2007). Report of the Ghana National Working Party on the Use of Calculators in the Basic Education Certificate Examination (BECE) Mathematics Paper. Mathematics Connection, 6(1), 57-65. https://doi.org/10.4314/mc.v6i1.21514

Miles, C. (2008). The use or non-use of calculators effects on student's ability to perform basic mathematics problems. in OTS Master's Level Projects and Papers, 89 . Retrieved From https://digitalcommons.odu.edu/ots masters projects/89

Ministry of Education, Science, and Sports. (2007). Teaching Syllabus for Mathematics (Junior High School 1 - 3) (Curriculum). Accra, Ghana.

National Council of Teachers of Mathematics. (2000). Principles and standards for school mathematics (Vol. 1). Reston, VA: The National Council of Teachers of Mathematics, Inc.

Ochanda, J. P., \& Indoshi, F. C. (2011). Challenges and benefits of using scientific calculators in the teaching and learning of Mathematics in secondary school education. Journal of Media and Communication Studies, 3(3), 102-111. Retrieved From https://academicjournals.org/journal/JMCS/article-full-text-pdf/4ECAA3111308

Pallant, J., \& Manual, S. S. (2007). A step by step guide to data analysis using SPSS for windows. SPSS Survival Manual. , New York: Open University Press.

Pelgrum, W. J. (2001). Obstacles to the integration of ICT in education: results from a worldwide educational assessment. Computers \& Education, 37(2), 163-178. https://doi.org/10.1016/s0360-1315(01)00045-8 
Pierce, R., \& Ball, L. 0. (2009). Perceptions that may affect teachers' intention to use technology in secondary mathematics classes. Educational Studies in Mathematics, 71(3), 299-317. https://doi.org/10.1007/s10649-008-9177-6

Salani, E. (2013). Teachers' beliefs and technology: Calculator use in mathematics instruction in junior secondary schools in Botswana. European Journal of Educational Research, 2(4), 151-166. https://doi.org/10.12973/eu-jer.2.4.151

Satianov, P. (2015). Using Calculators in Teaching Calculus. Mathematics Teaching Research Journal Online, 7(4). Retrieved From https://commons.hostos.cuny.edu/mtrj/wpcontent/uploads/sites/30/2018/12/v7n4-Using-Calculators-in-Teaching-

Calculus.pdf

Seeley, C. L. (2006). Technology is a tool. NCTM President's Message Retrieved February, p. 15. https://www.nctm.org/uploadedFiles/News and Calendar/Messages from the President/Archive/Cathy Seeley/2006 03 technology.pdf

Surry, D. W. (1997). Diffusion theory and instructional technology [Paper presentation]. The Annual Conference of the Association for Educational Communications and Technology, Albuquerque, New Mexico. Retrieved From http://myweb.fsu.edu/ajeong/eme5457/readings/Surry1997 DiffusionTheoryInstrT ech.pdf

Surry, D.W. \& Farquhar, J. D. (1997). Diffusion theory and instructional technology. Journal of Instructional Science and Technology, 2(1). 24-36.

Tabachnick, B. G., Fidell, L. S., \& Ullman, J. B. (2007). Using multivariate statistics (Vol. 5). Boston, MA: Pearson.

Tavakol, M., \& Dennick, R. (2011). Making sense of Cronbach's alpha. International Journal of Medical Education, 2, 53. https://doi.org/10.5116/ijme.4dfb.8dfd

Taylor, R. (1990). Interpretation of the correlation coefficient. Journal of Diagnostic Medical Sonography, 6(1), 35-39. https://doi.org/10.1177/875647939000600106

Tessmer, M. (1990). Environment analysis: A neglected stage of instructional design. Educational Technology Research and Development, 38(1), 55-64. https://doi.org/10.1007/bf02298248

Wilmot, E. M. (2015). High school teachers' knowledge for teaching algebra: A comparison of Ghana and the US. British Journal of Education, 3(2), 61-74. Retrieved From http://www.eajournals.org/wp-content/uploads/High-School-Teachers---Knowledge-For-Teaching-Algebra-A-Comparison-Of-Ghana-And-The-Us..pdf 